\title{
Utilization of Fly Ash For the Pretreatment Process of Rubber Industry Wastewater Processing Using Hybrid Membrane UF-RO
}

\author{
Meta Mediana ${ }^{1}$, Subriyer Nasir ${ }^{2 *}$, Hermansyah $^{3}$, Agung Mataram ${ }^{4}$ \\ ${ }^{1}$ Graduate Program Student, Chemical Engineering Magister Program, Universitas Sriwijaya, Indonesia \\ ${ }^{2}$ Dept. of Chemical Engineering, Faculty of Engineering, Sriwijaya University, Indonesia \\ ${ }^{3}$ Dept. of Chemistry, Faculty of Mathematics and Natural Sciences, Sriwijaya University, Indonesia \\ ${ }^{4}$ Dept. of Mechanical Engineering, Faculty of Engineering, Sriwijaya University, Indonesia \\ *Corresponding Author: subriyer@unsri.ac.id
}

Article history

\begin{tabular}{|c|c|c|c|}
\hline Received & Received in revised form & Accepted & Available online \\
\hline 14 February 2019 & 16 March 2019 & 30 March 2019 & 30 March 2019 \\
\hline
\end{tabular}

\begin{abstract}
This research was conducted to treat rubber industry wastewater by using fly-ash as an adsorbent and hybrid membrane UF-RO to produce clean water. In this research was analyzed the effect of flow rate of wastewater treatment to remove turbidity, zinc, and iron. The applied flow rate of membrane separation was of $7 \mathrm{~L} / \mathrm{min}$ and 14 $\mathrm{L} / \mathrm{min}$ and the operation time was of $90 \mathrm{~min}$ respectively. The rejection concentration of turbidity, zinc, and iron decreased with increasing the flow rate at adsorbent fly-ash. Whereas at the hybrid membrane UF-RO, the rejection concentration of turbidity, zinc, and iron increased with increasing the flow rate. The maximum rejection of turbidity was $24.26 \%$, 95\%, and $67.89 \%$ for adsorbent fly-ash, UF membrane, and RO membrane respectively. The maximum rejection of zinc was $91.67 \%, 59.70 \%$, and $14.81 \%$ for adsorbent fly-ash, UF membrane, and RO membrane respectively. The maximum rejection of iron was $62.24 \%$ and $21.62 \%$ for adsorbent fly-ash, UF membrane respectively. The pollutants concentration in the permeate was met the quality standards of the Indonesian health department through the decision of the Minister of Health number 907 of 2002 concerning supervision of the quality of drinking water.

Keywords: adsorbent, fly-ash, hybrid, rubber, UF-RO
\end{abstract}

Abstrak (Indonesian): Penelitian ini dilakukan untuk mengolah air limbah industri karet menggunakan fly-ash sebagai adsorben dan membran hybrid UF-RO untuk menghasilkan air bersih. Dalam penelitian ini dianalisis pengaruh laju alir untuk menghilangkan kekeruhan, seng, dan besi. Laju alir yang digunakan adalah $7 \mathrm{~L} / \mathrm{menit}$ dan 14 $\mathrm{L} /$ menit dan waktu operasi masing-masing adalah 90 menit. Konsentrasi kekeruhan, seng, dan besi menurun dengan meningkatnya laju alir pada adsorben fly-ash. Sedangkan pada membran hybrid UF-RO, konsentrasi kekeruhan, seng, dan besi meningkat dengan meningkatnya laju alir. Konsentrasi penurunan nilai kekeruhan maksimum masingmasing adalah $24,26 \%, 95 \%$, dan 67,89\% untuk fly-ash adsorben, membran UF, dan membran RO. Konsentrasi penurunan maksimum seng masing-masing adalah $91,67 \%, 59,70 \%$, dan $14,81 \%$ untuk adsorben fly-ash, membran UF, dan membran RO. Konsentrasi penurunan maksimum besi masing-masing adalah $62,24 \%$ dan $21,62 \%$ untuk adsorben fly-ash, membran UF. Konsentrasi polutan di permeat memenuhi standar kualitas departemen kesehatan Indonesia melalui keputusan menteri kesehatan nomor 907 tahun 2002 tentang pengawasan kualitas air minum.

Kata kunci: adsorben, fly-ash, hybrid, karet, UF-RO

\section{Introduction}

Indonesia has the largest rubber plantation land in the world with a land area of 3,616,694 hectares [1]. Indonesia is the second largest rubber-producing country after Thailand. Along with the size of rubber products owned, the growth of the rubber processing industry can develop well. The positive impact of the growth of the industry is decreased in the unemployment rate and can improve the standard of living of the people. Rubber is one commodity that is able to contribute a large contribution in efforts to increase the country's devisa. However, the growth of this industry also has a negative impact on the process, namely, the waste produced can disrupt the environment and public health. One of the wastes produced is wastewater.
Wastewater from industry contains dissolved solids, high acidity or alkalinity, and heavy metals [2]. Heavy metals are major sources of toxic materials [3]. A large amount of zinc can cause health problems, such as anemia, vomiting, skin irritations, nausea and stomach cramps $[4,5]$. Wastewater treatment products that have met the quality standards of the Indonesian health department through the decision of the Minister of Health number 907 of 2002 can be reused as drinking [6].

There are several types of rubber industry wastewater treatment that have been carried out, such as using direct contact membrane distillation (DCMD) process can significantly reduce the level of total organic carbon (TOC), total dissolved solid (TDS), 
sulfate, color, turbidity and conductivity in rubber industry wastewater of almost $96 \%$ [7], a combination of physicochemical and ozonation processes, the results showed that the use of the chemical coagulation process with iron chloride $\left(\mathrm{FeCl}_{3} .7 \mathrm{H}_{2} \mathrm{O}\right)$ in the first stage of this study reduced COD by $37 \%$ from the initial amount $(0.56 \mathrm{~g} / \mathrm{L})$. The optimal dose and $\mathrm{pH}$ ranges are 0.775 $\mathrm{g} / \mathrm{l}$ and 6.5 respectively. When using $\mathrm{Al}_{2}\left(\mathrm{SO}_{4}\right)_{3}$, the COD reduction rate was $42 \%$, and the optimal dose and $\mathrm{pH}$ range were $0.45 \mathrm{~g} / \mathrm{L}$ and 6.5-7 respectively. After the ozonation process, COD is reduced to $70.75 \%$ and $90.6 \%$ [8], The processing of rubber industry wastewater currently uses more conventional methods and the use of aerobic and anaerobic bacteria [9].

Therefore, it is necessary to carry out appropriate technological innovations in wastewater treatment, one of which is using a membrane combined with the pretreatment process so that it can reduce the tendency for flux to decrease during operating time due to depositional material on the membrane surface, known as fouling. To reduce the buildup of material on the membrane, preliminary treatment can be carried out using sand filters and fly-ash adsorbents, so as to reduce the workload of the membrane and extend the lifetime of the membrane. Fly-ash can be used as an adsorbent because it has large pores [10]. Fly-ash can remove organic contaminants because they contain high carbon, have a large surface area, and contain elements of Al, $\mathrm{Fe}, \mathrm{Ca}, \mathrm{Mg}$, and $\mathrm{Si}$ [11]. In recent years, research about the fly-ash as adsorbent has been done, such as fly-ash is capable of removing heavy metals $\mathrm{Zn}^{2+}, \mathrm{Pb}^{2+}$ in dyes [12], fly-ash can be used as an adsorbent in the $\mathrm{FeCl}_{3}$ - coal fly ash (CFA) hybrid process and succeed in reducing pollutants by up to $80 \%$ [13], the use of coal fly ash (CFA)-Bed can reduce color, TSS, COD, and turbidity by $88 \%, 92 \%, 67 \%$ and $89 \%$ in industrial coloring wastewater [14], fly-ash can eliminate 15.88 $\mathrm{mg} / \mathrm{g} \mathrm{Fe}$ (II) and $12.74 \mathrm{mg} / \mathrm{g} \mathrm{Zn} \mathrm{(II)} \mathrm{[15],} \mathrm{fly-ash} \mathrm{can}$ reduce the value of $\mathrm{COD}, \mathrm{BOD}$, and TS in domestic waste by up to $60 \%$ [16], fly-ash as an adsorbent is also supported by research on fly-ash can reduce $\mathrm{Zn}^{2+}, \mathrm{Pb}^{2+}$, and As (V) ions [17].

Membranes are defined as a porous, thin film, semipermeable media which functions to separate molecular size particles (species) in a system of solutions. Species that have a larger size than the membrane pore will be held while the smaller size of the membrane pore will pass through the membrane pore [18]. The process of separation with membranes can occur due to the pressing force which results in mass transfer through the membrane.

The ability of membranes to reduce metals has been done by mathematical modeling of zinc removal from wastewater using nanofiltration and osmosis membranes [3], using an ultrafiltration membrane to reduce the turbidity value to below 1 NTU [19].

This study is to combine the pretreatment process including sand filter and adsorption using fly-ash as an adsorbent. Followed by ultrafiltration membrane and reverse osmosis membrane with variations in flow rate, so that it can find out the best conditions in treating rubber industry wastewater. The research conducted focuses on reducing the value of turbidity, iron, and zinc.

\section{Methods}

\subsection{Materials}

Rubber industry wastewater sample comes from one of processing site industry at Palembang, South Sumatera, Indonesia. The fly-ash as an adsorbent was activated physically using an oven with the temperature $120^{\circ} \mathrm{C}$ inside the adsorption column. The main equipment to treat of adsorbent product using technology hybrid membrane UF - RO.

\subsection{Procedures}

Wastewater sample of the rubber industry from the sand filter column was analyzed of turbidity, iron, and zinc to know an initial concentration. Then, the sample was pumped to the adsorbent column. The water output from the adsorbent column was collected in the ultrafiltration membrane feed tank. From the ultrafiltration membrane feed tank, water was pumped to the ultrafiltration membrane column.

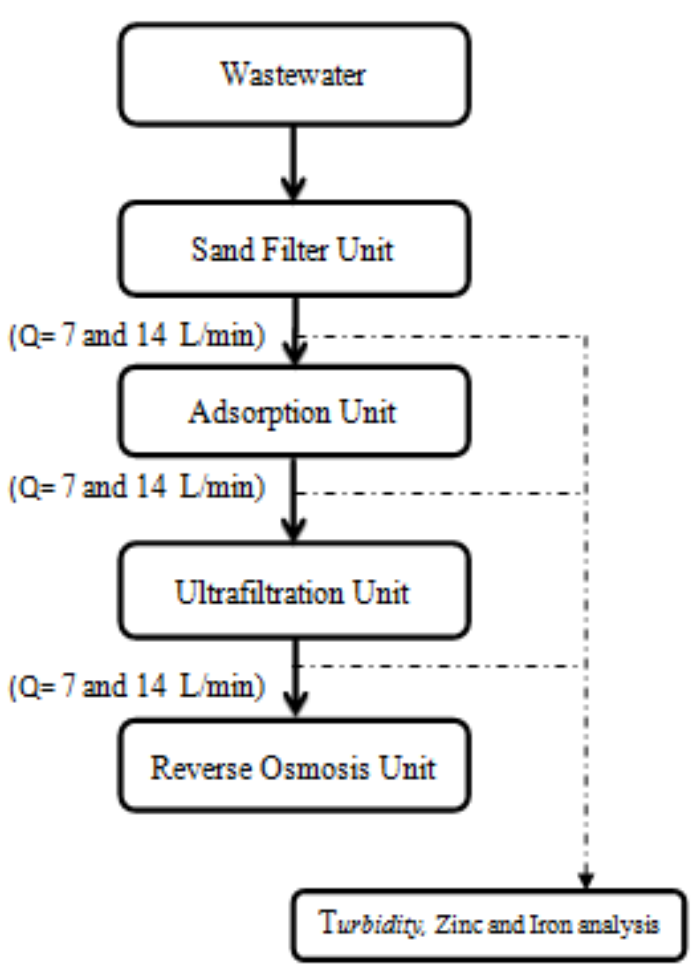

Figure 1 Experimental Set Up 
The output water from the ultrafiltration membrane was collected in a reverse osmosis membrane feed tank. From the reverse osmosis membrane feed tank, water was pumped into the reverse osmosis membrane column. The permeate was collected in the clean water tank. The output from each column processing was collected into the bottle sample to analysis the turbidity, iron, and zinc. The process was applied flow rate of 7 $\mathrm{L} / \mathrm{min}$ and $14 \mathrm{~L} / \mathrm{min}$ and the operation time was of 90 min respectively.

\subsection{Analysis}

The laboratory analyzes wastewater sample was performed for turbidity using Turbidity meter (Thermo Scientific type, merk: EUTECH TN-100), iron analysis based on Indonesian National Standard No. 06-6989.42004 using Spectrophotometer UV-200RS, and zinc analysis based on Indonesian National Standard No. 066989.7-2009 using Spectrophotometer UV-200RS.

\section{Results and Discussion}

\subsection{Analysis of Rubber Industry Wastewater}

Wastewater sample of the rubber industry from the sand filter column was analyzed of turbidity, iron, and zinc to know an initial concentration. The results of the initial analysis of rubber industry wastewater are shown in Table 1 below.

Table 1 Analysis of Rubber Industrial Wastewater

\begin{tabular}{llcccc} 
No. & Parameters & Unit & Value & $\begin{array}{c}\text { Maximum } \\
\text { Recommended }\end{array}$ & $\begin{array}{c}\text { Maximum } \\
\text { Allowed }\end{array}$ \\
\hline 1 & Turbidity & NTU & 15.66 & 5 & 25 \\
2 & Iron & $\mathrm{mg} / \mathrm{L}$ & 0.98 & 0.1 & 1 \\
3 & Zinc & $\mathrm{mg} / \mathrm{L}$ & 0.84 & 1 & 15 \\
\hline
\end{tabular}

Table 1 shows that the water from the pretreatment using sand filter still has iron and zinc and the turbidity value is quite high compared to the recommended maximum value based on the Republic of Indonesia Ministry of Health through the Ministry of Health No.907 Th. 2002. Therefore, in the rubber industry wastewater, it is necessary to carry out an advanced pretreatment process using fly-ash as an adsorbent to optimize the performance of hybrid membranes ultrafiltration and reverse osmosis.

\subsection{Effect of Flow Rate on Decreasing Turbidity Value}

Data on the effect of the flow rate on the value of turbidity are presented in Figure 2 below.

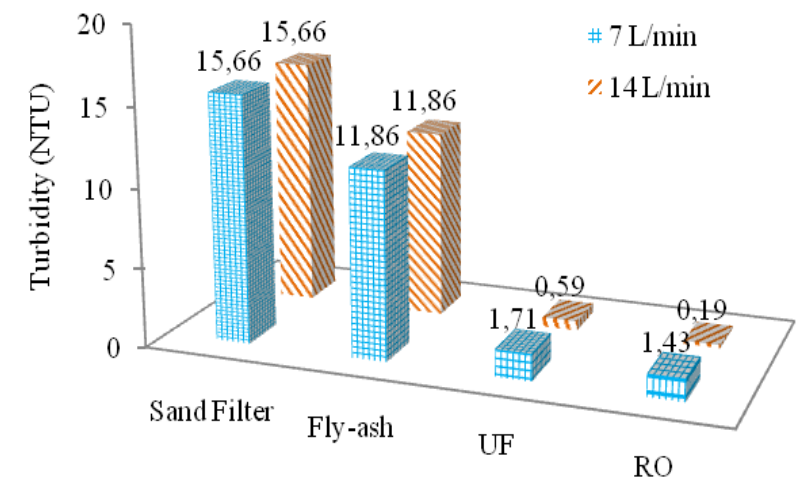

Figure 2 Effect of Flow Rate on Turbidity

Turbidity test at flow rate $7 \mathrm{~L} / \mathrm{min}$ and $14 \mathrm{~L} / \mathrm{min}$ as seen in Figure 2. From these results indicate that the flow rate does not affect the decrease in the concentration of turbidity in the adsorbent process. Percent decrease in turbidity both at flow rate $7 \mathrm{~L} / \mathrm{min}$ and $14 \mathrm{~L} / \mathrm{min}$ fly-ash adsorbent by $24.26 \%$. Whereas in the hybrid membrane UF-RO, turbidity rejection concentration increases with increasing flow rate. The maximum rejection of turbidity that occurs at a flow rate of $14 \mathrm{~L} / \mathrm{min}$, which is $95 \%$ in the ultrafiltration membrane and $67.89 \%$ in the reverse osmosis membrane. This occurs because the membrane operation requires a flow rate relatively high so that it can push the feed to separate it from pollutants.

\subsection{Effect of Flow Rate on Decreasing Iron Value}

Data on the effect of flow rate on decreasing iron values is presented in Figure 3 below.

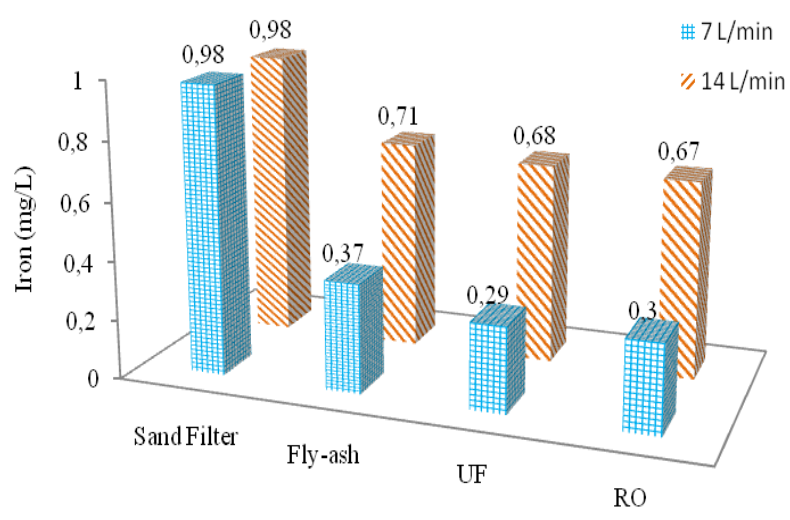

Figure 3 Effect of Flow Rate on Decrease Iron

Figure 3 shows the effects of flow rate on decrease iron in both the adsorbent column and the ultrafiltration and reverse osmosis membranes. The decrease in optimum iron value occurs at flow rate $7 \mathrm{~L} / \mathrm{min}$, which is $62.24 \%$ in the adsorbent column, this is because the feed contact time with the adsorbent is longer than at the flow rate $14 \mathrm{~L} / \mathrm{min}$ so that the removal is more optimal. The ultrafiltration membrane has an optimal decrease in iron value of $21.62 \%$. Whereas in reverse osmosis membranes there tends to be no decrease in 
iron value compared to the output value of the ultrafiltration membrane.

\subsection{Effect of Flow Rate on Decreasing Zinc}

Data on the effect of flow rate on decreasing zinc values are presented in Figure 4 below.

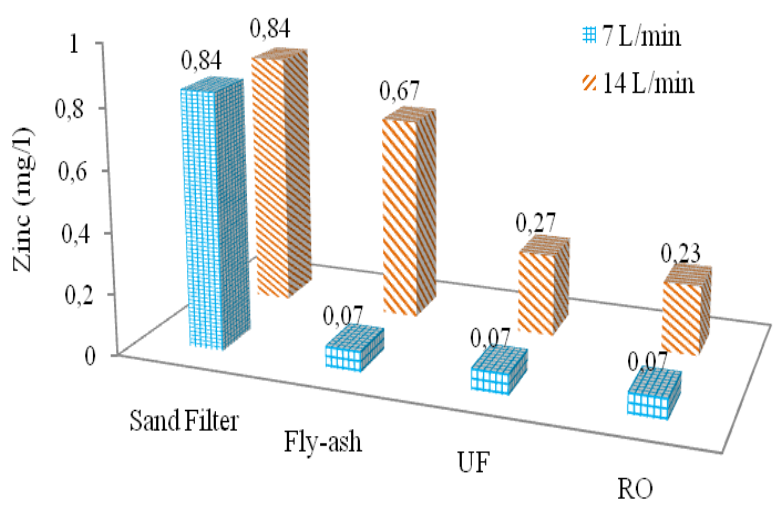

Figure 4 Effect of Flow Rate on Decrease Zinc

Figure 4 shows that the flow rate effects the decrease in the value of zinc in the adsorbent column. The optimum decrease occurred at $7 \mathrm{~L} / \mathrm{min}$ flow rate of $91.67 \%$, this was due to longer feed contact time with the adsorbent compared to the $14 \mathrm{~L} / \mathrm{min}$ flow rate so that the reduction was more optimal. While for both ultrafiltration and reverse osmosis membranes the optimum decrease occurred at the flow rate of 14 $\mathrm{L} / \mathrm{min}$, which is $59.70 \%$ in the ultrafiltration membrane and $14.81 \%$ in the reverse osmosis membrane, this is in accordance with the working principle of the membrane which requires strong pressure to separate pure solution with particles contained in it.

\section{Conclusion}

The results of the analysis showed that the rejection concentration of turbidity, zinc, and iron decreased with increasing the flow rate at adsorbent flyash. Whereas at the hybrid membrane UF-RO, the rejection concentration of turbidity, zinc, and iron increased with increasing the flow rate. The maximum rejection of turbidity was $24.26 \%, 95 \%$, and $67.89 \%$ for adsorbent fly-ash, UF membrane, and RO membrane respectively. The maximum rejection of zinc was $91.67 \%, 59.70 \%$, and $14.81 \%$ for adsorbent flyash, UF membrane, and RO membrane respectively. The maximum rejection of iron was $62.24 \%$ and $21.62 \%$ for adsorbent fly-ash, UF membrane respectively. The pollutants concentration in the permeate was met the quality standards of the Indonesian health department through the decision of the Minister of Health Republic Indonesia number 907 of 2002 concerning supervision of the quality of drinking water.

\section{Acknowledgment}

My gratitude to all parties who have helped and supported in realizing this research, especially my supervisors Prof.Ir. Subriyer Nasir, M.S., Ph.D. and Hermansyah, S.Si., M.Si., Ph.D.

\section{References}

[1] Direktorat Jenderal Perkebunan Indonesia 20132015.

[2] Nasir, S., Putri, E., dan Elita, I. “ Penyisihan Ion Kadmium pada Limbah Cair Pabrik Pulp \& Paper dengan Menggunakan Membran Keramik”. Jurnal Teknik Kimia, Vol.20, No. 2, page 3, 2014.

[3] Salih, M.H., and Al-Alawy, A.F. "Mathematical Modelling of Zinc Removal from Wastewater by Using Nanofiltration and Reverse Osmosis Membranes". International Journal of Science and Research (IJSR), January 2018.

[4] Addai, M. K., 2014. "Removal and Recovery of Heavy Metals by Nickel Smelter Slag". M.Sc. thesis, Western Ontario University.

[5] Fu, F. and Wang, Q. "Removal of Heavy Metal Ions from Wastewaters: A Review". Journal of Environmental Management. 92, 407-418, 2011.

[6] Departemen Kesehatan Republik Indonesia melalui Keputusan Menteri Kesehatan Nomor 907 Tahun 2002 tentang Pengawasan Kualitas Air Minum.

[7] Mokhtar, N.M., Lau, W.J., Ismail, A.F., and Veerasamy, D. "Membrane Distillation Technology for Treatment of Wastewater from Rubber Industry in Malaysia". Published by Elsevier B.V., Peer-review under responsibility of Assembly Technology and Factory Management/Technische Universität Berlin.

[8] Mohammadi, M., Man, H.C., Hassan, M.A., and Yee, P.L. "Treatment of wastewater from rubber industry in Malaysia". African Journal of Biotechnology Vol. 9(38), pp. 6233-6243, 20 September, 2010.

[9] Bada, S.O., et. al. "Evaluation and Treatment of Coal Fly Ash for Adsorption Application". Leonardo Electronic Journal of Practices and Technologies, 12:37-48, 2008.

[10] Kolemen, S. "The Zinc Adsorption by Using Orhaneli Fly Ash, Bentonite, and Molasses in Wastewater". E-Journal UNPAR Water Air Soil Pollution 224(1367): 1-11, 2013.

[11] Visa, M. "Heavy Metals Removal on DyeModified Fly Ash Substrates". World of Coal Ash (WOCA) Conference-May 9-12, 2011, in Denver, CO, USA.

[12] Massoudinejad, M., Mehdipour-Rabori, M., dan Dehghani , M.H. "Treatment of Natural Rubber Industry Wastewater Through a Combination of 
Physicochemical and Ozonation Processes". J Adv Environ Health Res, Vol. 3, No. 4, Autumn 2015.

[13] Shah, A.K., Ali, Z.M., Memon, A.R., Laghari, A.J., Mughal, M.A., Shah, S.F.A., Saleem, H. "Exploitation of Low Cost Coal Fly Ash Adsorbent with Coagulants for the Treatment of Industrial Complex Nature Dyes Wastewater". International Journal of Scientific \& Engineering Research, Volume 4, Issue 9, September-2013.

[14] Shah, S.F.A., Aftab, A., Soomro, N., Nawaz, M.S., Vafai, K. "Waste Water Treatment-Bed of Coal Fly Ash for Dyes and Pigments Industry". Pak. J. Anal. Environ. Chem. Vol. 16, No. 2, p 48 -56, 2015.

[15] Ashfaq, A. and Kaifiyan, M. "Simultaneous Biosorption of Iron (II) and Zinc (II) onto Flyash from Aqueous Solutions”. International Journal of Current Microbiology and Ap plied Sciences, Volume 5, Number 7, pp. 117-120, 2016.

[16] Sanas, M.V., Gawande, S.M. "Fly Ash using in Waste Water Tratment". International Journal of Emerging Engineering Research and Technology, Volume 4, Issue 6, PP 1 1-14, June 2016.

[17] Karanac, dkk.2017. The Removal of $\mathrm{Zn}^{2+}, \mathrm{Pb}^{2+}$, and $\mathrm{As}(\mathrm{V})$ Ions by Lime Activated Fly Ash and Valorization of the Exhausted Adsorbent. Article in Waste Management, August 2018. Kesting, R.E. 1971. Synthetic Polymeric Membrane. New York: McGraw-Hill Book Company.

[18] Maree, P. Drinking water production by ultrafiltration of Songhuajiang River with PAC adsorption. South Africa: Thesis, master of engineering (chemical engineering) in the Faculty of Engineering at Stellenbosch University, 